\title{
Drimane Sesquiterpenoids from the Mangrove-Derived Fungus Aspergillus ustus
}

\author{
Huinan Zhou, Tianjiao Zhu, Shengxin CAI, Qianqun Gu, and Dehai Li* \\ Key Laboratory of Marine Drugs, Chinese Ministry of Education, School of Medicine and Pharmacy, Ocean University of \\ China; Qingdao 266003, P. R. China. \\ Received January 7, 2011; accepted March 29, 2011; published online March 31, 2011
}

Five new drimane sesquiterpenes $(1-5)$ together with 14 known analogues $(6-19)$ were isolated from laboratory cultures of a mangrove-derived fungus Aspergillus ustus. Their structures were established by spectroscopic methods and antitumor activities were evaluated by sulforhodamine B (SRB) and 3-(4,5-dimethylthiazol2-yl)-2,5-diphenyltetrazolium bromide (MTT) methods.

Key words drimane sesquiterpene; Aspergillus ustus; mangrove-derived fungus

Fungi from mangrove have attracted much attention for their unique living conditions of wave-energy tidal mudflats, high moisture level, high salt concentration and lack of oxygen. ${ }^{1)}$ This fungal group has been widely recognized as rich source of active secondary metabolites. ${ }^{2,3}$ As part of our ongoing search for novel bioactive compounds from microorganisms isolated from unusual or specialized ecological niches, ${ }^{4-6)}$ the culture extract of a fungus strain (Aspergillus ustus), isolated from the rhizosphere soil of the mangrove Acrostichum aureurm grown in Guangxi Province of China, showed cytotoxic activity against P388 (mice lymphocytic leukemia) cell line. The chemical composition research on the EtOAc extract of the A. ustus fermentation led us to identify five new drimane sesquiterpenes $(\mathbf{1}-\mathbf{5})$ together with 14 known analogues (Fig. 1). ${ }^{1,7-12)}$ Herein, we report the structural elucidations and cytotoxic activities of these metabolites against P388, HL-60 (human promyelocytic leukemia cells), K562 (human erythromyeloblastoid leukemia cells) and BEL-7402 (human hepatoma cells).

Compound 1 was obtained as a white powder. The molecular formula was determined as $\mathrm{C}_{16} \mathrm{H}_{28} \mathrm{O}_{3}$ on the basis of its high resolution-electrospray ionization-mass spectra (HRESI-MS) peak at $\mathrm{m} / \mathrm{z} 291.1930[\mathrm{M}+\mathrm{Na}]^{+}$(Calcd for $\mathrm{C}_{16} \mathrm{H}_{28} \mathrm{O}_{3} \mathrm{Na}$ : 291.1936), indicating 3 degrees of unsaturation. The ${ }^{1} \mathrm{H}-\mathrm{NMR}$ spectrum (Table 1) disclosed the presence of five methyls, including three aliphatic single methyls $[\delta 0.91$ $(3 \mathrm{H}, \mathrm{s}), 0.98(3 \mathrm{H}, \mathrm{s})$, and $1.03(3 \mathrm{H}, \mathrm{s})]$, one olefinic methyl $[\delta 1.75(3 \mathrm{H}, \mathrm{s})]$, and one methoxy $[\delta 3.20(3 \mathrm{H}, \mathrm{s})] ;$ one olefinic proton $[\delta 5.47(1 \mathrm{H}, \mathrm{br} \mathrm{s})]$, four methylenes $[\delta 1.63$ $(1 \mathrm{H}, \mathrm{td}, J=12.8,3.2 \mathrm{~Hz}) / 1.43(1 \mathrm{H}, \mathrm{m}), 1.46(1 \mathrm{H}, \mathrm{m}) / 1.37$ $(1 \mathrm{H}, \mathrm{m}), 1.27(1 \mathrm{H}, \mathrm{brd}, J=13.3 \mathrm{~Hz}) / 1.14(1 \mathrm{H}, \mathrm{td}, J=13.3$, $3.7 \mathrm{~Hz}), 3.40(1 \mathrm{H}, \mathrm{dd}, J=11.0,5.0 \mathrm{~Hz}) / 3.47(1 \mathrm{H}, \mathrm{dd}, J=11.0$, $5.0 \mathrm{~Hz}$ )], and two exchangeable protons. The ${ }^{13} \mathrm{C}-\mathrm{NMR}$ (distortionless enhancement by polarization transfer (DEPT)) spectrum (Table 2) displayed 16 carbon resonances, assignable to five methyls, four methylenes, three methines and four quaternary carbons. Apart from one degree of unsaturation occupied by a double bond, the remaining two degrees of unsaturation required $\mathbf{1}$ to contain a bicyclic core ring system. The aforementioned data implied that $\mathbf{1}$ was a drimane sesquiterpense. ${ }^{13)}$ The NMR resonances were similar to those reported for albrassitriol (20), but replacing one of the $\mathrm{OHs}$ by a methoxyl group. ${ }^{13)}$ The structure of $\mathbf{1}$ was further confirmed by ${ }^{1} \mathrm{H}-{ }^{1} \mathrm{H}$ correlation spectroscopy (COSY) and heteronuclear multiple bond connectivity (HMBC) correlations (Fig. 2). The connection of C-11 and C-9 was determined by the HMBC correlations from $\mathrm{H}-11$ to $\mathrm{C}-8$ and $\mathrm{C}-10$, and the location of $-\mathrm{OCH}_{3}$ at $\mathrm{C}-6$ was deduced via a correlation between the methoxy protons and C-6.

The relative configuration of $\mathbf{1}$ was determined by the nuclear Overhauser effect spectroscopy (NOESY) spectrum. Correlations between $\mathrm{H}-13$ and $\mathrm{H}-1 \mathrm{~b}_{(\mathrm{eq})}$ and between $\mathrm{H}-5$ and $\mathrm{H}-1 \mathrm{a}_{(\mathrm{ax})}$ suggested a trans-fused decalin nucleus. ${ }^{1)}$ The correlation between $\mathrm{H}-5$ and $6-\mathrm{OCH}_{3}$ indicated the configu-

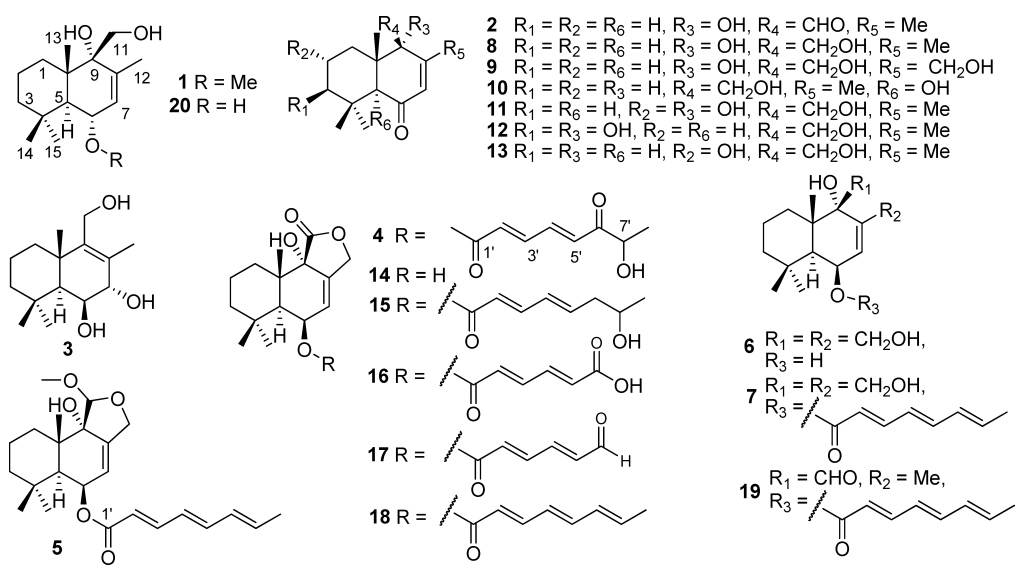

Fig. 1. Structures of Compounds $\mathbf{1}-\mathbf{2 0}$ 


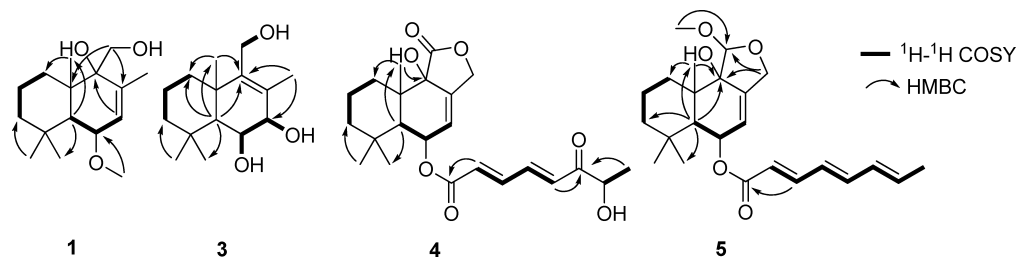

Fig. 2. Key $\mathrm{HMBC}$ and ${ }^{1} \mathrm{H}-{ }^{1} \mathrm{H}$ COSY Correlations for Compounds $\mathbf{1}, \mathbf{3}-\mathbf{5}$

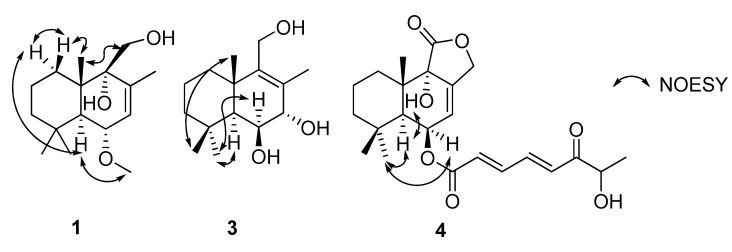

Fig. 3. Key NOESY Correlations for Compounds $\mathbf{1}, \mathbf{3}$ and $\mathbf{4}$

ration of H-5 and H-6 was trans. The cis configuration of $\mathrm{H}-$ 11 and $\mathrm{H}-13$ was deduced by the NOEs between $\mathrm{H}-13$ and $\mathrm{H}-$ 11. Thus, the overall relative configuration of compound $\mathbf{1}$ was analogous to albrassitriol (20), and we named this new metabolite $O$-methylalbrassitriol (1). ${ }^{13)}$

Compound 2, obtained as a white powder, was assigned to have the molecular formula $\mathrm{C}_{15} \mathrm{H}_{22} \mathrm{O}_{3}$ based on a HR-ESIMS peak at $m / z 249.1484[\mathrm{M}-\mathrm{H}]^{-}$, and thus possessing 5 degrees of unsaturation. The IR spectrum showed absorption bands at 3353, 1669 and $1713 \mathrm{~cm}^{-1}$, indicating the presence of hydroxyl, conjugated carbonyl, and aldehyde functionalities. The 1D-NMR data (Tables 1, 2) of compound 2 showed that its structure was closely related to that of the isolated known compound 8, except for the absence of $\mathrm{CH}_{2} \mathrm{OH}-9$ signals $\left[\delta_{\mathrm{H}} 3.65(1 \mathrm{H}, \mathrm{dd}, J=11.5,4.4 \mathrm{~Hz}) / 3.52(1 \mathrm{H}, \mathrm{dd}, J=11.5\right.$, $\left.4.9 \mathrm{~Hz}), 4.82(1 \mathrm{H}, \mathrm{dd}, J=4.9,4.4 \mathrm{~Hz}) ; \delta_{\mathrm{C}} 61.7(\mathrm{t})\right]$, and the presence of NMR resonances typical for an aldehyde group $\left[\delta_{\mathrm{H}} 9.81(1 \mathrm{H}, \mathrm{s}), \delta_{\mathrm{C}} 205.6(\mathrm{~d})\right]$, thus suggesting the replacement of the alcohol group in $\mathbf{8}$ by a aldehyde group in the new compound 2 . This conclusion was also supported by the apparent downshifted C-9 ( $\Delta 9.3 \mathrm{ppm})$, caused by the deshielding effect of the aldehyde functionality. A review of the structures for compounds $\mathbf{2}, \mathbf{8}, \mathbf{9}-\mathbf{1 3}$, suggests that these metabolites likely share the same biogenetic origin. Thus, they are expected to have the same relative configuration, which is further supported by comparing their optical rotation values $\left([\alpha]_{\mathrm{D}}^{25}-40^{\circ}\right.$ for $\mathbf{8} v s-25^{\circ}$ for 2$)$. Therefore, the structure of 2 was determined as $9 \alpha$-hydroxyl-9-formyl-5 $\alpha$ drim-7-en-6-one.

Compound 3 was separated as a white powder. The molecular formula was established as $\mathrm{C}_{15} \mathrm{H}_{26} \mathrm{O}_{3}$ on the basis of a HR-ESI-MS peak at $m / z 277.1754[\mathrm{M}+\mathrm{Na}]^{+}$. The ${ }^{1} \mathrm{H}-\mathrm{NMR}$ data (Table 1) showed four methyls, corresponding to three aliphatic single methyls $[\delta 0.90(3 \mathrm{H}, \mathrm{s}), 1.13(3 \mathrm{H}, \mathrm{s})$, and $1.21(3 \mathrm{H}, \mathrm{s})]$ and one olefinic methyl $[\delta 1.72(3 \mathrm{H}, \mathrm{s})]$, two oxygenated methines $[\delta 3.98(1 \mathrm{H}$, br s), $3.42(1 \mathrm{H}$, br d, $J=$ $5.0 \mathrm{~Hz})]$ and four methylenes $[\delta 1.69(1 \mathrm{H}$, brd, $J=12.8$ $\mathrm{Hz}) / 1.16(1 \mathrm{H}, \mathrm{m}), 1.64(1 \mathrm{H}, \mathrm{m}) / 1.44(1 \mathrm{H}, \mathrm{m}), 1.33(1 \mathrm{H}, \mathrm{brd}$, $J=12.8 \mathrm{~Hz}) / 1.10(1 \mathrm{H}, \mathrm{m}), 3.94(1 \mathrm{H}, \mathrm{dd}, J=11.5,3.7 \mathrm{~Hz}) / 3.88$ $(1 \mathrm{H}, \mathrm{dd}, J=11.5,3.7 \mathrm{~Hz})]$. This information together with the ${ }^{13} \mathrm{C}-\mathrm{NMR}$ data (Table 2 ) suggested that compound 3 had the similar molecular scaffold as $O$-methylalbrassitriol (1). The
${ }^{1} \mathrm{H}-{ }^{1} \mathrm{H}$ COSY experiment (Fig. 2) represented three structural moieties, $\mathrm{C}-1$ to $\mathrm{C}-3, \mathrm{C}-6(\mathrm{OH})$ to $\mathrm{C}-7(\mathrm{OH})$ and $\mathrm{C}$ $11(\mathrm{OH})$ to $\mathrm{C}-11$. The planar structure was determined by connecting these fragments based on the HMBC correlations from $\mathrm{H}-5$ to $\mathrm{C}-1$ and $\mathrm{C}-13$, from $\mathrm{H}-12$ to $\mathrm{C}-7$ and $\mathrm{C}-9$, and from $\mathrm{H}-13$ to $\mathrm{C}-1$ and $\mathrm{C}-9$.

The relative configuration of $\mathbf{3}$ was deduced from the NOESY experiment, coupling style and conformational analysis. The correlations between $\mathrm{H}-5$ and H-15, H-6 and H-15, indicated an $\alpha$ configuration for H-5, H-6 and H-15. The $\beta$ configuration of $\mathrm{H}-13$ was deduced by the correlation between $\mathrm{H}-14$ and $\mathrm{H}-13$. The resonances of $\mathrm{OH}-6$ and $\mathrm{OH}-7$ in ${ }^{1} \mathrm{H}-\mathrm{NMR}$ were doublets which indicated that these two hydroxyl protons are coupled with H-6 and H-7, respectively. The resonance assigned to $\mathrm{H}-7$ was an broad doublet $(J=5.0$ $\mathrm{Hz}$ ) whereas the signal for H-6 turned out to be a broad apparent singlet, thus supporting the coupling of H-6 and H-7 with their neighboring hydroxyl group protons. The above analysis indicates that the coupling between H-6 and H-7 is negligible (if any) and thus, the dihedral angle between H-6 and $\mathrm{H}-7$ must be nearly $90^{\circ}$. This suggests a trans configuration for H-6 and H-7 Hence, compound 3 was elucidated as drim-8-en-6 $\beta, 7 \alpha, 11$-triol.

Compound 4 was obtained as a colorless oil, of which HRESI-MS data indicated the molecular formula as $\mathrm{C}_{23} \mathrm{H}_{30} \mathrm{O}_{7}$. Comparison of the 1D-NMR data with those of the compound 15 suggested that they shared a similar molecular scaffold with differences only on the side chain. The major distinction was the replacement of $\mathrm{CH}_{2}-6^{\prime}\left[\delta_{\mathrm{C}} 42.6(\mathrm{t}) / \delta_{\mathrm{H}}\right.$ $2.22(2 \mathrm{H}, \mathrm{m})]$ by $\mathrm{C}=\mathrm{O}\left[\delta_{\mathrm{C}} 201.8(\mathrm{~s})\right]$, in agreement with the downfield chemical shift of C-7' $(\Delta 2.1 \mathrm{ppm})$ caused by the deshielding effect of the carbonyl group, further confirmed by ${ }^{1} \mathrm{H}-{ }^{1} \mathrm{H}$ COSY and HMBC correlations (Fig. 2).

The relative configuration of compound $\mathbf{4}$ was determined by NOESY correlations between H-6 and H-15, H-5 and H$15, \mathrm{H}-5$ and $\mathrm{OH}-9$, which displayed cis-configurations of $\mathrm{H}-$ $5, \mathrm{H}-6$ and $\mathrm{OH}-9$. The configuration of $\mathrm{C}-10$ was found the same as compound 15 by comparison of ${ }^{13} \mathrm{C}$ chemical shifts $\left(\delta_{\mathrm{C}} 37.3\right.$ for $4 v s . \delta_{\mathrm{C}} 37.3$ for 15$)$. Thus, the structure of 4 was determined as (6-strobilactone-B) ester of $(E, E)$-6-carbonyl-7-hydroxy-2,4-octadienoic acid.

Compound $\mathbf{5}$ was isolated as a colorless oil, its HR-ESIMS gave an exact mass of $m / z 425.2302$ for $[\mathrm{M}+\mathrm{Na}]^{+}$, suggesting the molecular formula $\mathrm{C}_{24} \mathrm{H}_{34} \mathrm{O}_{5}$. The $1 \mathrm{D}-\mathrm{NMR}$ data (Tables 1,2) were similar to that of the known compound 18. ${ }^{9)}$ The main differences include the presence of an additional methoxy resonance $\left[\delta_{\mathrm{H} / \mathrm{C}} 3.29(3 \mathrm{H}, \mathrm{s}) / 55.0(\mathrm{q})\right]$, meanwhile carbons C-9, C-11 and C-12 were shifted downfield at $2.9,5.5$, and $6.8 \mathrm{ppm}$, respectively. The new methoxy group was allocated at $\mathrm{C}-11$ based on the HMBC correlation between its protons and $\mathrm{C}-11$. Therefore, the planar structure 
Table 1. ${ }^{1} \mathrm{H}-\mathrm{NMR}$ Data for Compounds $\mathbf{1}-\mathbf{5}\left(600 \mathrm{MHz}, \mathrm{DMSO}-d_{6}, \delta\right.$ in ppm, $J$ in Hz)

\begin{tabular}{|c|c|c|c|c|c|}
\hline Position & 1 & 2 & 3 & 4 & 5 \\
\hline \multirow[t]{2}{*}{1} & $1.63 \operatorname{td}(12.8,3.2)$ & $2.03 \mathrm{td}(13.2,4.1)$ & $1.69 \mathrm{brd}(12.8)$ & $1.97 \mathrm{td}(13.3,3.9)$ & 1.17 brd (13.3) \\
\hline & $1.43 \mathrm{~m}$ & $1.03 \mathrm{~m}$ & $1.16 \mathrm{~m}$ & 1.85 brd (13.3) & $2.03 \mathrm{dd}(13.3,4.3)$ \\
\hline \multirow[t]{2}{*}{2} & $1.46 \mathrm{~m}$ & $1.51 \mathrm{~m}$ & $1.64 \mathrm{~m}$ & $1.62 \mathrm{~m}$ & $1.44 \mathrm{~m}$ \\
\hline & $1.37 \mathrm{~m}$ & $1.41 \mathrm{~m}$ & $1.44 \mathrm{~m}$ & $1.35 \mathrm{brd}(12.8)$ & $1.58 \mathrm{~m}$ \\
\hline \multirow[t]{2}{*}{3} & 1.27 brd (13.3) & 1.28 brd (13.3) & 1.33 brd (12.8) & 1.49 br d (13.3) & $1.23 \mathrm{~m}$ \\
\hline & $1.14 \operatorname{td}(13.3,3.7)$ & $1.11 \mathrm{~m}$ & $1.10 \mathrm{~m}$ & $1.20 \mathrm{~m}$ & 1.33 brd (12.4) \\
\hline 5 & $1.85 \mathrm{~d}(10.5)$ & $2.73 \mathrm{~s}$ & $1.26 \mathrm{brs}$ & $2.03 \mathrm{~d}(4.0)$ & $2.09 \mathrm{~d}(4.0)$ \\
\hline 6 & $3.66 \mathrm{dt}(10.5,1.9)$ & & 3.98 br s & $5.62 \mathrm{brs}$ & $5.58^{a)}$ \\
\hline $6-\mathrm{OCH}_{3}$ & $3.20 \mathrm{~s}$ & & & & \\
\hline 7 & 5.47 br s & $5.78 \mathrm{~d}(1.6)$ & 3.42 br d $(5.0)$ & 5.81 brs & $5.58^{a)}$ \\
\hline \multirow[t]{2}{*}{11} & $3.47 \mathrm{dd}(11.0,5.0)$ & $9.81 \mathrm{~s}$ & $3.94 \mathrm{dd}(11.5,3.7)$ & & $5.37 \mathrm{~s}$ \\
\hline & $3.40 \mathrm{dd}(11.0,5.0)$ & & $3.88 \mathrm{dd}(11.5,3.7)$ & & \\
\hline \multirow{3}{*}{$\begin{array}{l}11-\mathrm{OCH}_{3} \\
12\end{array}$} & & & & & $3.29 \mathrm{~s}$ \\
\hline & $1.75 \mathrm{~s}$ & $1.75 \mathrm{~d}(1.6)$ & $1.72 \mathrm{~s}$ & $4.89 \mathrm{~d}(12.4)$ & $3.64 \mathrm{~d}(9.1)$ \\
\hline & & & & $4.80 \mathrm{~d}(12.4)$ & $3.89 \mathrm{~d}(9.1)$ \\
\hline 13 & $0.91 \mathrm{~s}$ & $1.10 \mathrm{~s}$ & $1.21 \mathrm{~s}$ & $1.07 \mathrm{~s}$ & $1.10 \mathrm{~s}$ \\
\hline 14 & $0.98 \mathrm{~s}$ & $1.08 \mathrm{~s}$ & $1.13 \mathrm{~s}$ & $0.9 \mathrm{~s}$ & $0.93 \mathrm{~s}$ \\
\hline 15 & $1.03 \mathrm{~s}$ & $1.06 \mathrm{~s}$ & $0.90 \mathrm{~s}$ & $1.07 \mathrm{~s}$ & $1.08 \mathrm{~s}$ \\
\hline $2^{\prime}$ & & & & $7.32-7.36^{a)}$ & $5.92 \mathrm{~d}(15.1)$ \\
\hline $3^{\prime}$ & & & & 6.49 brd (13.6) & $7.21 \mathrm{dd}(15.1,11.0)$ \\
\hline $4^{\prime}$ & & & & 7.03 brd (13.6) & $6.35 \mathrm{dd}(15.1,11.0)$ \\
\hline $5^{\prime}$ & & & & $7.32-7.36^{a)}$ & $6.71 \mathrm{dd}(15.1,11.0)$ \\
\hline $6^{\prime}$ & & & & & $6.21 \mathrm{dd}(15.1,11.0)$ \\
\hline $7^{\prime}$ & & & & $4.25 \mathrm{~m}$ & $6.02 \mathrm{dq}(15.1,6.9)$ \\
\hline $8^{\prime}$ & & & & $1.20 \mathrm{~d}(6.8)$ & $1.80 \mathrm{~d}(6.9)$ \\
\hline $6-\mathrm{OH}$ & & & $4.29 \mathrm{~d}(4.0)$ & & \\
\hline 7-OH & & & $4.65 \mathrm{~d}(5.0)$ & & \\
\hline 9-OH & $4.24 \mathrm{~s}$ & $6.28 \mathrm{~s}$ & & $6.31 \mathrm{~s}$ & $5.07 \mathrm{~s}$ \\
\hline $11-\mathrm{OH}$ & $4.47 \mathrm{t}(5.0)$ & & $4.06 \mathrm{t}(3.7)$ & & \\
\hline $7^{\prime}-\mathrm{OH}$ & & & & $5.46 \mathrm{~d}(5.0)$ & \\
\hline
\end{tabular}

a) Overlapping signals.

Table 2. ${ }^{13} \mathrm{C}-\mathrm{NMR}$ Data for Compounds $\mathbf{1}-\mathbf{5}[(\mathbf{1}, \mathbf{2}, \mathbf{5}) 150 \mathrm{MHz},(\mathbf{3}, \mathbf{4})$ $100 \mathrm{MHz}, \mathrm{DMSO}-d_{6}, \delta$ in ppm]

\begin{tabular}{|c|c|c|c|c|c|}
\hline Position & 1 & 2 & 3 & 4 & 5 \\
\hline 1 & $33.0(\mathrm{t})$ & $32.4(\mathrm{t})$ & $37.8(t)$ & $29.6(\mathrm{t})$ & $33.1(\mathrm{t})$ \\
\hline 2 & $18.8(t)$ & $17.5(\mathrm{t})$ & $18.7(\mathrm{t})$ & $17.4(\mathrm{t})$ & $18.4(\mathrm{t})$ \\
\hline 3 & $43.7(t)$ & $42.6(t)$ & $42.8(\mathrm{t})$ & $44.4(t)$ & $44.9(t)$ \\
\hline 4 & 33.3 (s) & $32.5(\mathrm{~s})$ & 33.3 (s) & 33.3 (s) & $33.6(\mathrm{~s})$ \\
\hline 5 & 46.2 (d) & 54.4 (d) & 48.0 (d) & 44.2 (d) & 44.8 (d) \\
\hline 6 & 77.8 (d) & $199.4(\mathrm{~s})$ & 70.3 (d) & 66.5 (d) & 67.0 (d) \\
\hline $6-\mathrm{OCH}_{3}$ & $54.3(\mathrm{q})$ & & & & \\
\hline 7 & 126.3 (d) & 129.8 (d) & 75.0 (d) & $121.0(\mathrm{~d})$ & $121.2(\mathrm{~d})$ \\
\hline 8 & 137.9 (s) & $152.4(\mathrm{~s})$ & $129.0(\mathrm{~s})$ & $136.9(\mathrm{~s})$ & $145.1(\mathrm{~s})$ \\
\hline 9 & $75.0(\mathrm{~s})$ & $81.8(\mathrm{~s})$ & 142.7 (s) & 73.1 (s) & $79.7(\mathrm{~s})$ \\
\hline 10 & $42.4(\mathrm{~s})$ & $45.5(\mathrm{~s})$ & $38.0(\mathrm{~s})$ & $37.3(\mathrm{~s})$ & $39.6(\mathrm{~s})$ \\
\hline 11 & $62.5(\mathrm{t})$ & 205.6 (d) & $56.1(\mathrm{t})$ & $174.3(\mathrm{~s})$ & $103.3(\mathrm{~d})$ \\
\hline $11-\mathrm{OCH}_{3}$ & & & & & $55.0(\mathrm{q})$ \\
\hline 12 & 19.8 (q) & 19.6 (q) & 17.3 (q) & $68.2(\mathrm{t})$ & $73.0(\mathrm{t})$ \\
\hline 13 & 17.9 (q) & $34.2(\mathrm{q})$ & 21.0 (q) & 24.3 (q) & $19.8(q)$ \\
\hline 14 & $23.9(\mathrm{q})$ & $22.0(q)$ & 23.5 (q) & $18.3(\mathrm{q})$ & $33.2(q)$ \\
\hline 15 & $36.7(\mathrm{q})$ & $18.9(\mathrm{q})$ & $33.2(\mathrm{q})$ & $32.1(\mathrm{q})$ & $24.8(\mathrm{q})$ \\
\hline $1^{\prime}$ & & & & $164.6(\mathrm{~s})$ & $166.0(\mathrm{~s})$ \\
\hline $2^{\prime}$ & & & & 142.5 (d) & 120.4 (d) \\
\hline $3^{\prime}$ & & & & 128.8 (d) & 145.9 (d) \\
\hline $4^{\prime}$ & & & & 132.3 (d) & 128.0 (d) \\
\hline $5^{\prime}$ & & & & 138.6 (d) & 142.4 (d) \\
\hline $6^{\prime}$ & & & & $201.8(\mathrm{~s})$ & $131.8(\mathrm{~d})$ \\
\hline $7^{\prime}$ & & & & 71.5 (d) & 136.2 (d) \\
\hline $8^{\prime}$ & & & & $19.4(q)$ & $18.9(q)$ \\
\hline
\end{tabular}

of 5 was elucidated as $\left(2^{\prime} E, 4^{\prime} E, 6^{\prime} E\right)-6-\left(1^{\prime}\right.$-carboxyocta$2^{\prime}, 4^{\prime}, 6^{\prime}$-triene)-11,12-epoxy-9-hydroxy-11-methoxy-drim7-ene.
The relative configuration of $11-\mathrm{OCH}_{3}$ and $\mathrm{H}-5, \mathrm{H}-6$ in compound 5 could not be established due to the lack of definitive NOE correlations. The relative configuration between H-5 and H-6 was established by comparing their 13C-NMR chemical shift with compounds 1 and 4 . The similar chemical shift of compounds 5 and 4 [C-5 ( $\Delta 0.6 \mathrm{ppm}), \mathrm{C}-6(\Delta$ $0.5 \mathrm{ppm})]$, together with the relative big difference between compounds 5 and 1 [C-5 ( $\Delta 1.4 \mathrm{ppm}), \mathrm{C}-6$ ( $\Delta 10.8 \mathrm{ppm})]$ suggested that $\mathbf{5}$ shares the same relative configuration with metabolite 4. The OH-9 of compound 5 and those of compounds $4,14-18$ correlated with each other biogenetically and thus, they should share the same relative configuration.

The planar structures of compounds $\mathbf{3}$ and $\mathbf{4}$ are already registered in CAS (CAS No.: 1217857-65-2 for $\mathbf{3}$ and 1217868-38-6 for 4). But to the best of our knowledge, there are no data and references available for them. Hence, we still regarded them as new compounds in this communication. The remaining known metabolites were identified by comparing their spectroscopic data with that reported in the literature. ${ }^{1,7-12)}$

All compounds were evaluated for their cytotoxicities against P388, HL-60, K562 and BEL-7402 cell lines using the sulforhodamine B (SRB) ${ }^{14)}$ and 3-(4,5-dimethylthiazol2-yl)-2,5-diphenyltetrazolium bromide (MTT) ${ }^{14)}$ methods. Only compound $\mathbf{4}$ exhibited moderate cytotoxicity against the P388 cell line with $\mathrm{IC}_{50}$ value of $8.7 \mu \mathrm{M}$. The other compounds were inactive on the four cell lines mentioned above at a test concentration of $10 \mu \mathrm{M}$. Interestingly, the differences of cytotoxicities between compounds $\mathbf{4}$ and $\mathbf{1 5}$ on the P388 cell line indicated that the carbonyl at C-6' was necessary for 
the activity.

Drimane sesquiterpenoids are widely spread metabolites of terrestrial plants, marine animals, and fungi. To the best of our knowledge, natural drimanes containing a double bond between C-8 and C-9 are only found in terrestrial plants ${ }^{15,16}$ and oils. ${ }^{17)}$ Thus, compound 3 constitutes the first of such drimanes reported from a fungus. Metabolites 4, 5, 7 and 15-19 are drimane sesquiterpenoids esterified at C-6, which were found only in Aspergillus sp. until now. ${ }^{1,7-9)}$ Due to their diverse biological activities, which include antifeedant, cytotoxic, and piscicidal among others, drimane sesquiterpenoids have attracted the attention of the synthetic community. ${ }^{18)}$ The biological evaluation on other bioassays of all compounds herein reported is still in progress.

\section{Experimental}

General Experimental Procedures Optical rotations were obtained on a JASCO P-1020 digital polarimeter (JASCO Inc., Tokyo, Japan). IR spectrum was taken on a Nicolet NEXUS 470 spectrophotometer (Thermo Electron Corporation, Madison, WI, U.S.A.) in $\mathrm{KBr}$ disks. ${ }^{1} \mathrm{H}-,{ }^{13} \mathrm{C}-\mathrm{NMR}$ and DEPT spectra and 2D-NMR were recorded on a JEOL JNMECP600 (JEOL Ltd., Tokyo, Japan) and Bruker DRX 400 (Bruker Ltd., Germany) spectrometers using TMS as internal standard, and chemical shifts were recorded as $\delta$ values. ESI-MS were measured on a Q-TOF Ultima Global GAA076 LC mass spectrometer (Waters Corporation, Milford, MA, U.S.A.). Semipreparative HPLC was performed using an ODS column [YMC-pack ODS-A, $10 \times 250 \mathrm{~mm}, 5 \mu \mathrm{m}$, (YMC Co., Ltd., Kyoto, Japan), $4 \mathrm{ml} / \mathrm{min}$ ]. TLC and column chromatography (CC) were performed on plates precoated with silica gel GF254 $(10-40 \mu \mathrm{m})$ and over silica gel (200-300 mesh, Qingdao Marine Chemical Factory, Qingdao, China) and Sephadex LH-20 (GE Healthcare, Uppsala, Sweden), respectively.

Fungal Material The strain A. ustus was isolated from the rhizosphere soil of the mangrove plant Acrostichum aureurm grown in Guangxi Province of China. The voucher specimen is deposited in our laboratory at $-20^{\circ} \mathrm{C}$. The working strain was prepared on potato dextrose agar slants and stored at $4{ }^{\circ} \mathrm{C}$.

Fermentation, Extraction, and Isolation The fungus A. ustus was incubated for $11 \mathrm{~d}$ on a rotary shaker at $180 \mathrm{rpm}$ at $28^{\circ} \mathrm{C}$ in two hundreds of $500 \mathrm{ml}$ conical flasks containing liquid medium ( $150 \mathrm{ml} /$ flask $)$, composed of glucose $(10.0 \mathrm{~g} / 1)$, maltose $(20.0 \mathrm{~g} / 1)$, mannitol $(20.0 \mathrm{~g} / 1)$, monosodium glutamate $(10.0 \mathrm{~g} / \mathrm{l}), \mathrm{KH}_{2} \mathrm{PO}_{4}(0.5 \mathrm{~g} / 1), \mathrm{MgSO}_{4} \cdot 7 \mathrm{H}_{2} \mathrm{O}(0.3 \mathrm{~g} / \mathrm{l})$, corn steep liquor $(1.0 \mathrm{~g} / 1)$, yeast extract $(3.0 \mathrm{~g} / 1)$, and seawater after adjusting to $\mathrm{pH}$ 7.0. The fermented whole broth was filtered through cheese cloth to separate into supernatant and mycelia. The former was extracted three times with EtOAc, while the latter was extracted three times with acetone and concentrated under reduced pressure to afford an aqueous solution which was extracted three times with EtOAc. Both EtOAc solutions were combined and concentrated under reduced pressure to give the crude extract $(95 \mathrm{~g})$.

The crude extract was subjected to vacuum liquid chromatography over silica gel column using a gradient elution with petroleum ether $(\mathrm{PE}) / \mathrm{CH}_{2} \mathrm{Cl}_{2} /$ $\mathrm{MeOH}$ to give 6 fractions. Fraction 1 was chromatographed on a silica gel column, eluted with PE/EtOAc $(1: 1)$ to provide 3 subfractions (Fr. 1.1-Fr. 1.3). Compounds 7 (20 mg, $\left.t_{\mathrm{R}} 19.5 \mathrm{~min}\right)$ and $\mathbf{1 8}\left(25 \mathrm{mg}, t_{\mathrm{R}} 12.2 \mathrm{~min}\right)$ were obtained from Fr. 1.2 by semipreparative HPLC eluting with $80 \%$ aqueous $\mathrm{MeOH}$. Fraction 1.1 and Fr. 1.3 were further purified by semipreparative HPLC to give compounds 19 (7.8 $\mathrm{mg}, t_{\mathrm{R}} 15.7 \mathrm{~min} / 85 \%$ aqueous $\left.\mathrm{MeOH}\right)$ and $5\left(3 \mathrm{mg}, t_{\mathrm{R}} 10.7 \mathrm{~min} / 80 \%\right.$ aqueous $\left.\mathrm{MeOH}\right)$, respectively. Fraction 2 was separated by Sephadex LH-20 eluting with $\mathrm{CH}_{2} \mathrm{Cl}_{2} / \mathrm{MeOH}(1: 1)$ to provide 2 subfractions (Fr. 2.1 and Fr. 2.2). Fraction 2.1 was further fractionated by semipreparative HPLC to give compounds 10 ( $3 \mathrm{mg}, t_{\mathrm{R}} 12.2 \mathrm{~min} / 65 \%$ aqueous $\mathrm{MeOH}$ ) and 1 (43 mg, $t_{\mathrm{R}} 15.3 \mathrm{~min} / 65 \%$ aqueous $\left.\mathrm{MeOH}\right)$. Fraction 2.2 was rechromatographed on a silica gel column, eluted with PE/EtOAc $(3: 1)$, and on semipreparative HPLC to afford compound 16 (4 mg, $t_{\mathrm{R}} 14.8 \mathrm{~min} /$ $70 \%$ aqueous $\mathrm{MeOH}$ ). Fraction 3 was chromatographed on a silica gel column using a step gradient elution of PE/acetone to provide 2 fractions, Fr. 3.1 and Fr. 3.2. The two fractions were further purified by semipreparative HPLC to give compounds $8\left(5 \mathrm{mg}, t_{\mathrm{R}} 11.5 \mathrm{~min} / 55 \%\right.$ aqueous $\left.\mathrm{MeOH}\right)$ and 14 ( $29 \mathrm{mg}, t_{\mathrm{R}} 13.8 \mathrm{~min} / 65 \%$ aqueous $\mathrm{MeOH}$ ), respectively. Fraction 5 was purified by sephadex LH-20, eluting with $\mathrm{MeOH}$ to provide 2 fractions, Fr. 5.1 and Fr. 5.2. Fr. 5.1 was chromatographed on a silica gel column using a step gradient elution of PE/acetone to provide 2 subfractions, Fr. 5.1.1 and Fr.
5.1.2. By semipreparative HPLC compounds $9\left(10 \mathrm{mg}, t_{\mathrm{R}} 11.9 \mathrm{~min} / 60 \%\right.$ aqueous $\mathrm{MeOH}), 2\left(2 \mathrm{mg}, t_{\mathrm{R}} 12.9 \mathrm{~min} / 60 \%\right.$ aqueous $\left.\mathrm{MeOH}\right)$ and $12(6 \mathrm{mg}$, $t_{\mathrm{R}} 14.3 \mathrm{~min} / 60 \%$ aqueous $\left.\mathrm{MeOH}\right)$ were obtained from Fr. 5.1.1, and compounds $6\left(10 \mathrm{mg}, t_{\mathrm{R}} 15.2 \mathrm{~min} / 55 \%\right.$ aqueous $\left.\mathrm{MeOH}\right), 11\left(3 \mathrm{mg}, t_{\mathrm{R}} 9.8 \mathrm{~min} /\right.$ $60 \%$ aqueous $\mathrm{MeOH})$, and $13\left(3 \mathrm{mg}, t_{\mathrm{R}} 11.3 \mathrm{~min} / 60 \%\right.$ aqueous $\mathrm{MeOH}$ ) were purified from Fr. 5.1.2. Fraction 5.2 was also chromatographed on a silica gel column using a step gradient elution of PE/acetone to provide 3 subfractions, Fr. 5.2.1, Fr. 5.2.2 and Fr. 5.2.3. The separation of Fr. 5.2.1 by semipreparative HPLC led to the isolation of compounds $3\left(2 \mathrm{mg}, t_{\mathrm{R}} 9.5 \mathrm{~min} / 75 \%\right.$ aqueous $\mathrm{MeOH})$ and $15\left(1.8 \mathrm{mg}, t_{\mathrm{R}} 12.7 \mathrm{~min} / 75 \%\right.$ aqueous $\left.\mathrm{MeOH}\right)$. Fraction 5.2.2 and Fr. 5.2.3 were subjected to semipreparative HPLC, and resulted in the isolation of compounds $17\left(4 \mathrm{mg}, t_{\mathrm{R}} 14.5 \mathrm{~min} / 70 \%\right.$ aqueous $\left.\mathrm{MeOH}\right)$ and $4\left(1.5 \mathrm{mg}, t_{\mathrm{R}} 16.2 \mathrm{~min} / 60 \%\right.$ aqueous $\left.\mathrm{MeOH}\right)$, respectively.

$O$-Methylalbrassitriol (1): White, amorphous powder $(\mathrm{MeOH}),[\alpha]_{\mathrm{D}}^{25}$ $-5.5^{\circ}(c=0.1, \mathrm{MeOH}), \mathrm{IR}(\mathrm{KBr}) \mathrm{cm}^{-1}: 3369,3001,2950,2917,1738$, 1441, 1364, 1082, 962, 607, 433, ${ }^{1} \mathrm{H}-\mathrm{NMR}$ (DMSO- $d_{6}, 600 \mathrm{MHz}$ ) and ${ }^{13} \mathrm{C}-$ NMR (DMSO- $d_{6}, 150 \mathrm{MHz}$ ), see Table 1 and Table 2, HR-ESI-MS $\mathrm{m} / \mathrm{z}$ 291.1930 [M+Na $]^{+}$(Calcd for $\left.\mathrm{C}_{16} \mathrm{H}_{28} \mathrm{O}_{3} \mathrm{Na} 291.1936\right)$.

$9 \alpha$-Hydroxyl-9-aldehyde-5 $\alpha$-drim-7-en-6-one (2): White, amorphous powder $(\mathrm{MeOH}),[\alpha]_{\mathrm{D}}^{25}-25.4^{\circ}(c=0.1, \mathrm{MeOH}), \operatorname{IR}(\mathrm{KBr}) \mathrm{cm}^{-1}: 33532950$, 2927, 1713, 1669, 1337, 976, 649, ${ }^{1} \mathrm{H}-\mathrm{NMR}$ (DMSO- $d_{6}, 600 \mathrm{MHz}$ ) and ${ }^{13} \mathrm{C}-$ NMR (DMSO- $d_{6}, 150 \mathrm{MHz}$ ) see Table 1 and Table 2, HR-ESI-MS $m / z$ 249.1484 [M-H] $]^{-}$(Calcd for $\mathrm{C}_{15} \mathrm{H}_{21} \mathrm{O}_{3} 249.1491$ ).

Drim-8-en-6 $\beta, 7 \beta, 11$-triol (3): White, amorphous powder $(\mathrm{MeOH}),[\alpha]_{\mathrm{D}}^{25}$ $1.62^{\circ}(c=0.1, \mathrm{MeOH}), \mathrm{IR}(\mathrm{KBr}) \mathrm{cm}^{-1}: 3328,2916,1464,1396,1022,{ }^{1} \mathrm{H}-$ NMR (DMSO- $d_{6}, 600 \mathrm{MHz}$ ) and ${ }^{13} \mathrm{C}-\mathrm{NMR}\left(\mathrm{DMSO}-d_{6}, 100 \mathrm{MHz}\right)$ see Table 1 and Table 2, HR-ESI-MS $m / z$ 277.1754 [M+Na $]^{+}\left(\right.$Calcd for $\mathrm{C}_{15} \mathrm{H}_{26} \mathrm{O}_{3} \mathrm{Na}$ 277.1780).

(6-Strobilactone-B) Ester of (E,E)-6-Carbonyl-7-hydroxy-2,4-octadienoic Acid (4): Colorless oil $(\mathrm{MeOH}),[\alpha]_{\mathrm{D}}^{25}-216.4^{\circ}(c=0.1, \mathrm{MeOH}), \mathrm{IR}(\mathrm{KBr})$ $\mathrm{cm}^{-1}$ : 3747, 3649, 1777, 1704, 1518, 665, 424, ${ }^{1} \mathrm{H}-\mathrm{NMR}$ (DMSO-d $d_{6}$, $600 \mathrm{MHz}$ ) and ${ }^{13} \mathrm{C}-\mathrm{NMR}$ (DMSO- $d_{6}, 100 \mathrm{MHz}$ ) see Table 1 and Table 2, HR-ESI-MS $m / z$ 417.1932 [M-H] ${ }^{-}$(Calcd for $\mathrm{C}_{23} \mathrm{H}_{29} \mathrm{O}_{7} 417.1913$ ).

(2'E,4'E,6'E)-6-(1'-Carboxyocta-2', $4^{\prime}, 6^{\prime}$-triene)-11,12-epoxy-9-hydroxy11-methoxy-drim-7-ene $(5)$ : Colorless oil $(\mathrm{MeOH}),[\alpha]_{\mathrm{D}}^{25}-136.3^{\circ}(c=0.1$, $\mathrm{MeOH})$, IR $(\mathrm{KBr}) \mathrm{cm}^{-1}: 3442,2923,1712,1460,1102,1011,662,{ }^{1} \mathrm{H}-$ NMR (DMSO- $d_{6}, 600 \mathrm{MHz}$ ) and ${ }^{13} \mathrm{C}-\mathrm{NMR}$ (DMSO- $d_{6}, 150 \mathrm{MHz}$ ) see Table 1 and Table 2, HR-ESI-MS $m / z 425.2302[\mathrm{M}+\mathrm{Na}]^{+}\left(\mathrm{Calcd}\right.$ for $\mathrm{C}_{24} \mathrm{H}_{34} \mathrm{O}_{5} \mathrm{Na}$ 425.2304).

In Vitro Cytotoxicity Assays In the MTT assay, the cell line was grown in RPMI-1640 supplemented with 10\% fetal bovine serum (FBS) under a humidified atmosphere of $5 \% \mathrm{CO}_{2}$ and $95 \%$ air at $37^{\circ} \mathrm{C}$. Cell suspensions $(200 \mu \mathrm{l})$ at a density of $5 \times 10^{4}$ cells $\mathrm{ml}^{-1}$ were plated in 96 -well microtiter plates and incubated for $24 \mathrm{~h}$. The test compound solutions $(2 \mu \mathrm{l}$ in dimethyl sulfoxide (DMSO)) at different concentrations were added to each well and further incubated for $72 \mathrm{~h}$ under the same conditions. MTT solution $(20 \mu \mathrm{l}$ of a $5 \mathrm{mg} \mathrm{ml}^{-1}$ solution in IPMI-1640 medium) was added to each well and incubated for $4 \mathrm{~h}$. An old medium $(150 \mu \mathrm{l})$ containing MTT was then gently replaced by DMSO and pipetted to dissolve any formazan crystals formed. Absorbance was then determined on a SPECTRA MAX PLUS plate reader at $540 \mathrm{~nm}$.

In the SRB assay, cell suspensions $(200 \mu \mathrm{l})$ were plated in 96 -cell plates at a density of $2 \times 10^{5}$ cells $\mathrm{ml}^{-1}$. Then the test compound solutions $(2 \mu \mathrm{l}$ in DMSO) at different concentrations were added to each well and further incubated for $24 \mathrm{~h}$. Following drug exposure, the cells were fixed with $12 \%$ trichloroacetic acid and the cell layer was stained with $0.4 \%$ SRB. The absorbance of SRB solution was measured at $515 \mathrm{~nm}$. Dose response curves were generated and the $\mathrm{IC}_{50}$ values were calculated from the linear portion of $\log$ dose response curves.

Acknowledgments This work was financially supported by the Chinese National Science Fund (No. 30973627), the public projects of State Oceanic Administration (No. 2010418022-3), the Shandong Provincial Natural Science Fund (No. ZR2009CZ016) and the program for Changjiang Scholars and Innovative Research Team in University (No. IRT0944). We also thank Dr. Alban R. Pereira (Scripps Institution of Oceanography, La Jolla) for his assistance preparing this manuscript.

\section{References}

1) Lu Z. Y., Wang Y., Miao C. D., Liu P. P., Hong K., Zhu W. M., J. Nat. Prod., 72, 1761-1767 (2009).

2) Lin Y. C., Wu X. Y., Feng S., Jiang G. C., Luo J. H., Zhou S. N., Vrijmoed L. L. P., Jones E. B. G., Krohn K., Steingröver K., Zsila F., J. Org. Chem., 62, 6252-6256 (2001). 
3) Xu M. J., Gessner G., Groth I., Lange C., Christner A., Bruhn T., Deng Z. W., Li X., Heinemann S. H., Grabley S., Bringmann G., Sattler I., Lin W. H., Tetrahedron, 63, 435-444 (2007).

4) Lu Z. Y., Lin Z. J., Wang W. L., Du L., Zhu T. J., Fang Y. C., Gu Q. Q., Zhu W. M., J. Nat. Prod., 71, 543-546 (2008).

5) Wang W. L., Lu Z. Y., Tao H. W., Zhu T. J., Fang Y. C., Gu Q. Q., Zhu W. M., J. Nat. Prod., 70, 1558-1564 (2007).

6) Du L., Zhu T. J., Fang Y. C., Gu Q. Q., Zhu W. M., J. Nat. Prod., 71, 1343-1351 (2008).

7) Liu H. B., Edrada-Ebel R., Ebel R., Wang Y., Schulz B., Draeger S., Müller W. E. G., Wray V., Lin W. H., Proksch P., J. Nat. Prod., 72 1585-1588 (2009).

8) Uosaki Y., Yoshida M., Ogawa T., Saitoh Y., J. Antibiot., 49, 6-12 (1996).

9) Hayes M. A., Wrigley S. K., Chetland I., Reynolds E. E., Ainsworth A. M., Renno D. V., Latif M. A., Cheng X. M., Hupe D. J., Charlton P.,
Doherty A. M., J. Antibiot., 49, 505-512 (1996).

10) Bernardi M. D., Mellerio G., Vidari G., Vita-Finzi P., J. Chem. Soc., Perkin Trans. 1, 1983, 2739-2743 (1983).

11) Garlaschelli L., Vidari G., Tetrahedron, 45, 7371-7378 (1989).

12) Urones J. G., Díez D., Gómez P. M., Marcos I. S., Basabe P., Moro R. F., J. Chem. Soc., Perkin Trans. 1, 1997, 1815-1818 (1997).

13) William A. A., Luis M. P., J. Nat. Prod., 50, 408-417 (1987).

14) Cai S. X., Li D. H., Zhu T. J., Wang F. P., Xiao X., Gu Q. Q., Helv. Chim. Acta, 93, 791-795 (2010).

15) Rifai Y., Arai M. A., Koyano T., Kowithayakorn T., Ishibashi M., J. Nat. Prod., 73, 995-997 (2010).

16) Toyota M., Ooiso Y., Kusuyama T., Asakawa Y., Phytochemistry, 35, 1263-1265 (1994).

17) Weyerstahl P., Marschall H., Weirauch M., Thefeld K., Surburg H., Flavour Fragrance J., 13, 295-318 (1998).

18) Jansen B. J. M., de Groot A., Nat. Prod. Rep., 21, 449—477 (2004). 